\title{
PENGARUH TEKNIK RELAKSASI NAFAS DALAM DAN AROMATERAPI LAVENDER UNTUK PENURUNAN TINGKAT KECEMASAN PASIEN PRE OPERASI APENDIKSITIS
}

\author{
Ria Oktasari Nurdin, Sariman Pardosi, Dahrizal \\ Politeknik Kesehatan Kementerian Kesehatan Bengkulu, Jurusan Keperawatan, \\ Jalan Indragiri Nomor 03 Padang Harapan Bengkulu \\ riaoktasari3006@gmail.com
}

\begin{abstract}
The surgical procedure gives reactions such as fear, anger, anxiety and anxiety. Anxiety is a normal phenomenon in new experiences and things that have not been tried. The magnitude of anxiety depends on the expected outcome of the surgery, the benefits and the type of organ being removed. This research is to know the effect of breath relaxation technique in using lavender aromatherapy to decrease the anxiety level of pre surgical patient appendiksitis in RSUD Dr. M.Yunus Bengkulu. Research using Pre-experimental with one-group pretest-posttest design. The sample was appendixitis patients totaling 20 people taken by accidental sampling. Data analysis with paired t test. The data showed averages before the intervention anxiety value 28.70 and after intervention 23.70 . There is difference of anxiety value after intervention $(\mathrm{p}=0,001 \leq \alpha 5 \%$ meaning, there is decrease of anxiety value before and after intervention. Conclusions and Suggestions: The nurse provides information and asks the family to provide lavender aromatherapy as a preparation for surgery to reduce preoperative patient anxiety.
\end{abstract}

Keywords: Anxiety, Pre Operation, Aromatherapy, Lavender.

Abstrak: Prosedur operasi memberikan reaksi seperti ketakutan, marah, gelisah dan kecemasan. Kecemasan merupakan fenomena normal pada pengalaman-pengalaman baru dan hal-hal yang belum penah dicoba. Besarnya kecemasan tergantung pada harapan hasil operasi, manfaat dan jenis organ yang diangkat. Penelitian ini untuk mengetahui pengaruh teknik relaksasi nafas dalam menggunakan aromaterapi lavender terhadap penurunan tingkat kecemasan pasien pre operasi apendiksitis di RSUD Dr. M.Yunus Bengkulu. Penelitian menggunakan Pre-eksperimental dengan one-group pretestposttest design. Sampel adalah pasien apendiksitis berjumlah 20 orang diambil secara accidental sampling. Analisa data dengan uji $\mathrm{t}$ paired.Data menunjukan rata-rata sebelum intervensi nilai kecemasan 28,70 dan sesudah intervensi 23,70. Ada perbedaan nilai kecemasan setelah dilakukan intervensi $(\mathrm{p}=0,001 \leq \alpha 5 \%$ artinya, terdapat penurunan nilai kecemasan sebelum dan sesudah intervensi. Perawat ruangan memberikan informasi dan meminta kepada keluarga untuk menyediakan aromaterapi lavender sebagai persiapan operasi untuk menurunkan kecemasan pasien pre operasi.

Kata Kunci: Kecemasan, Pre Operasi, Aromaterapi, Lavender.

Operasi atau pembedahan merupakan salah satu tindakan medis yang penting dalam pelayanan kesehatan. Tindakan pembedahan merupakan salah satu tindakan medis yang bertujuan menyelamatkan nyawa, mencegah kecacatan, dan komplikasi (Hasri, 2012). Prosedur operasi akan memberikan suatu reaksi emosional bagi pasien seperti ketakutan, marah, dan gelisah serta kecemasan (Muttaqin \& Sari, 2009). Tindakan pembedahan merupakan salah satu tindakan medis yang akan mendatangkan stressor terhadap integritas seseorang. Pembedahan membangkitkan reaksi stress baik fisiologis maupun psikologis. Salah satu respon psikologis adalah cemas.

Kecemasan merupakan fenomena normal pada pengalaman-pengalaman baru dan hal-hal yang belum penah dicoba (Ibrahim, 2008). Kecemasan biasanya dilatar belakangi berbagai alasan diantaranya adalah ancaman kematian, nyeri, perdarahan, perubahan peran dan kemandirian, kerusakan integritas kulit, 
anestesi yang digunakan, kehilangan waktu kerja, kehilangan pekerjaan dan tanggung jawab terhadap keluarga. Besarnya kecemasan tergantung pada harapan hasil operasi, manfaat dan jenis organ yang diangkat (Mau, 2013).

Secara teoritis kecemasan dapat diatasi dengan menggunakan terapi farmakologi dan terapi nonfarmakologi. Pada penelitian ini peneliti menggunakan aromaterapi lavender sebagai terapi penyembuhan. Salah satu aromaterapi yang dapat digunakan untuk menurunan tingkat kecemasan adalah lavender yang sebagian besar mengandung linalool dan linalool asetat sekitar 30-60\% dari total berat minyak, dimana linalool merupakan kandungan yang diketahui dapat memberikan efek relaksasi (Nuraini, 2014). Kemudian berdasarkan teori yang dikemukakan oleh Dewi (2011) Aromaterapi lavender dapat menurunkan tingkat kecemasan dan memberikan perasaan yang lebih rileks, karena pada saat menghirup aromaterapi lavender, komponen kimia akan masuk ke kesistim limbik pada otak. . Sistem limbik merupakan pusat nyeri, senang, marah, takut, depresi, dan berbagai emosi lainnya. Hipotalamus berperan sebagai relay dan regulator, memuncul kan pesan-pesan ke bagian otak serta bagian tubuh yang lain. Pesan yang diterima kemudian diubah menjadi tindakan berupa pelepasan senyawa elektrokimia yang menyebabkan euporia, relaks atau sedative. Aromaterapi lavender bekerja dengan merangsang sel saraf penciuman dan mempengaruhi sistem kerja limbik dengan meningkatkan perasaan positif dan rileks. Minyak lavender memiliki banyak potensi karena terdiri atas beberapa kandungan seperti monoterpene, hidrokarbon, camphene, limonene, geraniol lavandulol, nerol dan sebagian besar mengandung linalool dan linalool asetat dengan jumlah sekitar 30$60 \%$ dari total berat minyak, dimana linalool merupakan kandungan aktif utama untuk rileksasi (Nuraini, 2014).
Dampak positif aromaterapi terhadap penurunan tingkat kecemasan ini disebabkan karena aromaterapi lavender diberikan secara langsung (inhalasi). Mekanisme melalui penciuman jauh lebih cepat dibanding rute yang lain dalam penanggulangan problem emosionl seperti stress dan kecemasan, termasuk sakit kepala, karena hidung/ penciuman mempunyai kontak langsung dengan bagian-bagian otak yang bertugas merangsang terbentuknya efek yang ditimbulkan oleh aromaterapi. Hidung sendiri bukanlah organ untuk membau, tetapi hanya memodifikasi suhu dan kelembaban udara yang masuk.

Berdasarkan hasil data-data diatas dan penelitian sebelumnya, mak peneliti merasa tertarik untuk melakukan penelitian tentang pengaruh teknik relaksasi nafas dalam dengan aromaterapi lavender terhadap penurunan tingkat kecemasan pada pasien pre operasi apendiksitis di RSUD Dr. M. Yunus Bengkulu tahun 2017.

\section{BAHAN DAN CARA KERJA}

Jenis penelitian ini merupakan penelitian kuantitatif, dengan desain penelitian Pre-Ekspremen dengan menggunakan desain One-Grup PretestPosttest Design. Sampel dalam penelitian ini sebanyak 20 responden. Penelitian ini dilakukan di RSUD Dr. M.Yunus Bengkulu pengambilan data dilakukan pada tanggal 17 Februari 2017 s.d 17 Maret 2017. Penelitian ini bertujuan untuk mengetahui pengaruh teknik relaksasi nafas dalam dengan aromaterapi lavender terhadap penurunan tingkat kecemasan pada pasien pre operasi apendiksitis di instalasi rawat inap ruang seruni dan flamboyan RSUD Dr. M. Yunus Bengkulu tahun 2017. 


\section{HASIL}

Karakteristik responden

Tabel 1 Distribusi frekuensi karakteristik responden

\begin{tabular}{clll}
\hline Karakteristik & & Frekuensi & Persen \\
\hline Umur & $<20$ tahun & 1 & 5,0 \\
& 20-40 tahun & 12 & 60,0 \\
& $41-60$ tahun & 7 & 35,0 \\
& Total & 20 & 100.0 \\
\multirow{5}{*}{ Jenis Kelamin } & Laki-laki & 12 & 60,0 \\
& Perempuan & 8 & 40,0 \\
\hline & Total & 20 & 100,0 \\
\hline
\end{tabular}

Berdasarkan tabel 5.1 kategori umur responden terbanyak pada usia 20-40 tahun $(60,0 \%)$, usia $41-60$ tahun $(35,0 \%)$, dan pada usia $<20$ tahun $(5,0 \%)$, sebagian besar responden berjenis kelamin laki-laki (60\%).

Tabel 2. Perubahan Tingkat Kecemasan Pasien Pre Operasi Sebelum dan Sesudah Dilakukan Relaksasi Nafas Dalam Dengan Aromaterapi Lavender di RSUD Dr. M.Yunus Bengkulu Tahun 2017

\begin{tabular}{lllll}
\hline Tingk & Jumlah & Tingkat & Tingkat & Tingkat \\
at & & Kecema & Kecemas & Kecemasa \\
Kece & & san & an & n Sesudah \\
masan & & Sesudah & Sesudah & Intervensi \\
Sebel & & $\begin{array}{l}\text { Interven } \\
\text { si }\end{array}$ & $\begin{array}{l}\text { Intervens } \\
\text { um }\end{array}$ & Berat \\
Interv & & Ringan & Sedang & \\
ensi & & - & - & \\
\hline $\begin{array}{l}\text { Ringa } \\
\text { n }\end{array}$ & - & & & \\
Sedan & 11 & 2 & 9 & - \\
g & & & & 1 \\
Berat & 9 & 1 & 7 & \\
Total & 20 & 3 & 16 & \\
\hline
\end{tabular}

Berdasarkan tabel 2 tingkat kecemasaan sebelum dilakukan intervensi (relaksasi nafas dalam dengan aromaterapi lavender) yang berada pada tingkat kecemasan ringan tidak ada responden, pada tingkat kecemasan sedang ada 11 responden, dan pada tingkat kecemasan berat ada 9 responden. Sesudah dilakukan intervensi (relaksasi nafas dalam dengan aromaterapi lavender) responden yang berada pada tingkat kecemasan berat berkurang menjadi tingkat kecemasan ringan ada 1 responden, berkurang menjadi tingkat kecemasan sedang sebanyak 7 responden.
Tabel 3 Distribusi perbedaan rata-rata Tingkat

Kecemasan Pasien Pre Operasi Sebelum dan Sesudah

Dilakukan Relaksasi Nafas Dalam Dengan

Aromaterapi Lavender di RSUD Dr. M.Yunus

Bengkulu Tahun 2017

\begin{tabular}{llllll}
\hline $\begin{array}{l}\text { Nilai } \\
\text { Kecemasa } \\
\mathrm{n}\end{array}$ & $\begin{array}{l}\text { Mea } \\
\mathrm{n}\end{array}$ & SD & SE & $\begin{array}{l}95 \% \mathrm{CI} \\
\text { for mean }\end{array}$ & $\begin{array}{l}\mathrm{p} \\
\text { Valu } \\
\mathrm{e}\end{array}$ \\
\hline $\begin{array}{l}\text { Sebelui- } \\
\text { Sesudah } \\
\text { intervenin }\end{array}$ & 5,00 & 3,30 & 0,740 & $3,451-$ & 0,00 \\
$\mathrm{~g}$ & & 9 & & 6,549 & 1 \\
\hline
\end{tabular}

Berdasarkan tabel 5.3 rata-rata perubahan nilai kecemasan setelah responden diberikan intervensi adalah 5,00 dengan standar deviasi 3,309. Hasil uji statistik menunjukkan bahwa nilai $\mathrm{p}=0,001$ $\leq \alpha 5 \%$, artinya ada Pengaruh teknik relaksasi nafas dalam dengan aromaterapi lavender terhadap penurunan tingkat kecemasan pasien pre operasi apendiksitis sesudah dibandingkan dengan sebelum dilakukan tindakan relaksasi nafas dalam dengan aromaterapi lavender.

\section{PEMBAHASAN}

Pada pembahasan akan diuraikan tentang makna hasil penelitian serta membandingkannya dengan teori dan penelitian terkait, serta mendiskusikan hasil penelitian yang telah diuraikan pada bab hasil. Sesuai dengan tujuan khusus penelitian ini, maka pembahasan hasil penelitian dilakukan untuk mengetahui tingkat kecemasan sebelum dan sesudah dilakukan tindakan relaksasi nafas dalam dengan aromaterapi lavender dan pengaruh teknik relaksasi nafas dalam dengan aromaterapi lavender terhadap penurunan tingkat kecemasan pada pasien pre operasi apendiksitis di Instalasi rawat inap ruang seruni dan flamboyan RSUD Dr. M.Yunus Bengkulu Tahun 2017.

Gambaran Kecemasan Pasien Pre Operasi Apendiksitis Sebelum Dan Sesudah Dilakukan Tindakan Relaksasi Nafas Dalam Dengan Aromaterapi Lavender

Hasil penelitian menunjukkan sebagian kecil responden berada pada tingkat 
kecemasan berat sebelum intervensi dan setelah dilakukan intervensi sebagian besar responden berada pada tingkat kecemasan sedang, responden yang mengalami kecemasan berat hanya $5 \%$ dan yang mengalami kecemasan ringan $15 \%$. Hasil penelitian ini juga menunjukkan tidak ada responden yang tidak mengalami kecemasan. Hal ini dapat disebabkan karena sebagian besar responden adalah berusia 20-40 tahun disebabkan karena kecemasan dapat terjadi sebagai masa yang penuh dengan ketegangan emosional. Ketegangan emosional seringkali ditampakkan dalam kekhawatiran. Kekhawatiran yang timbul pada umumnya bergantung pada tercapainya penyesuaian terhadap persoalan yang dihadapi. Ketidakmampuan dalam mengatasi masalah akan menyebabkan gangguan emosional. Hasil ini sejalan dengan penelitian Apriansyah ( 2015) yang akan menjalani operasi, pasien yang mengalami kecemasan ringan $(52,5 \%)$ dan kecemasan sedang $(47,5 \%)$ dari 40 pasien rawat inap di ruang penyakit bedah dan non bedah.

Kecemasan merupakan fenomena normal pada pengalaman-pengalaman baru dan hal-hal yang belum penah dicoba, Ibrahim (2008). Kecemasan biasanya dilatar belakangi berbagai alasan diantaranya adalah ancaman kematian, nyeri, perdarahan, perubahan peran dan kemandirian, kerusakan integritas kulit, anestesi yang digunakan, kehilangan waktu kerja, kehilangan pekerjaan dan tanggung jawab terhadap keluarga. Besarnya kecemasan tergantung pada harapan hasil operasi, manfaat dan jenis organ yang diangkat,Mau (2013). Secara teoritis kecemasan dapat diatasi dengan menggunakan terapi farmakologi dan terapi nonfarmakologi. Pada penelitian ini peneliti menggunakan aromaterapi lavender sebagai terapi penyembuhan. Salah satu aromaterapi yang dapat digunakan untuk menurunan tingkat kecemasan adalah lavender yang sebagian besar mengandung linalool dan linalool asetat sekitar 30-60\% dari total berat minyak, dimana linalool merupakan kandungan yang diketahui dapat memberikan efek relaksasi (Nuraini, 2014).

Hasil penelitian pada tabel 5.1. menunjukkan rata-rata kecemasan sebelum dilakukan tindakan relaksasi nafas dalam dengan aromateapi lavender adalah 28,70 dan kecemasan sesudah dilakukan tindakan relaksasi nafas dalam dengan aromaterapi lavender adalah 23,70. Hal tersebut juga menunjukkan penurunan kecemasan semua responden. Hasil penelitian sejalan dengan penelitian yang dilakukan Arwani,dkk (2013) menunjukkan intervensi aromaterapi yang diberikan 2 jam sebelum operasi, kemudian dilakukan pengukuran skala kecemasan 1 jam sebelum operasi disimpulkan intervensi aromaterapi yang diberikan mendekati waktu operasi juga efektif terhadap penurunan kecemasan pada pasien pre operasi, dengan hasil pengukuran skala kecemasan tidak ditemukan responden dengan kecemasan berat dan terjadi peningkatan jumlah responden yang tidak cemas dari 6 orang menjadi 16 orang

Perbedaan Rata-Rata Kecemasan Pasien Pre Operasi Apendiksitis Sebelum Dan Sesudah Dilakukan Tindakan Relaksasi Nafas Dalam Dengan Aromaterapi Lavender

Hasil penelitian menunjukkan ada penurunan rata-rata kecemasan pasien pre operasi sesudah dibandingkan dengan sebelum dilakukan tindakan relaksasi nafas dalam dengan aromaterapi lavender adalah 5,00. Keadaan ini menunjukkan semua responden mengalami penurunan kecemasan pre operasi setelah dilakukan tindakan relaksasi nafas dalam dengan aromaterapi lavender.

Hasil observasi selama penelitian responden yang mengalami kecemasan ditandai dengan beberapa hal, diantaranya menjadi marah karena hal-hal kecil/sepele, mudah tersinggung, tidak tenang, mudah gelisah, ketakutan, sulit untuk beristirahat dan gangguan pola tidur, gangguan daya ingat, mulut terasa kering, kehilangan minat 
pada banyak hal, dan sering menarik nafas panjang, membutuhkan dukungan keluarga dan takut diri terhambat oleh tugas-tugas yang tidak bisa diselesaikan.

Hal ini sesuai dengan pendapat Andaners (2009), penyebab rasa cemas dapat dikelompokan menjadi 3 faktor, yaitu faktor biologis atau fisiologis, berupa ancaman akan kekurangan makanan, minuman, perlindungan dan keamanan. Faktor psikososial, ancaman terhadap konsep diri, kehilangan benda atau orang yang dicintai, perubahan status sosial ekonomi dan faktor perkembangan, yaitu ancaman pada masa bayi, anak, remaja.

Aromaterapi lavender yang dberiikan perawat bekerja dengan merangsang sel saraf penciuman dan mempengaruhi sistem kerja limbik dengan meningkatkan perasaan positif dan rileks. Aromaterapi yang digunakan melalui inhalasi atau dihirup akan masuk kedalam system limbic atau struktur bagian dalam dari otak, sistem ini sebagai pusat nyeri, senang, marah, takut, depresi dan berbagai emosi lainnya Keadaan ini sesuai dengan pendapat Kuntjoro (2002) yang menyatakan bahwa peran perawat sangat penting dalam penanggulangan kecemasan dan berupaya agar pasien tidak merasa cemas melalui asuhan keperawatan yang komprehensif secara biologis, psikologis, social, dan spiritual. Peran perawat sangat penting untuk memperikan support atau dukungan terhadap penurunan tingkat kecemasan pada pasien pre operasi.

Menurut Jong (1997), menyebutkan bahwa akibat dari kecemasan pasien pre operasi yang sangat hebat maka ada kemungkinan operasi tidak bisa dilaksanakan, karena pada pasien yang mengalami kecemasan sebelum operasi akan muncul kelainan seperti tekanan darah yang meningkat, sehingga apabila tetap dilakukan operasi akan dapat mengakibatkan penyulit terutama dalam menghentikan perdarahan, dan bahkan setelah operasi pun akan mengganggu proses penyembuhan. Hal ini sesuai dengan pendapat Dewi (2011), bahwa aromaterapi lavender dapat menurunkan tingkat kecemasan dan memberikan perasaan yang lebih rileks, karena pada saat menghirup aromaterapi lavender, komponen kimia akan masuk ke kesistim limbik pada otak. Sistem limbik merupakan pusat nyeri, senang, marah, takut, depresi, dan berbagai emosi lainnya. Hipotalamus berperan sebagai relay dan regulator, memuncul kan pesan-pesan ke bagian otak serta bagian tubuh yang lain. Pesan yang diterima kemudian diubah menjadi tindakan berupa pelepasan senyawa elektrokimia yang menyebabkan euporia, relaks atau sedative.

Hasil uji statistik menunjukkan bahwa nilai $\mathrm{p}=0,001 \leq \alpha 5 \%$, artinya ada Pengaruh teknik relaksasi nafas dalam dengan aromaterapi lavender terhadap penurunan tingkat kecemasan pasien pre operasi apendiksitis sesudah dibandingkan dengan sebelum dilakukan tindakan relaksasi nafas dalam dengan aromaterapi lavender.

\section{KESIMPULAN}

Karakteristik pasien pre operasi responden terbanyak pada umur 20-40 tahun dengan persentase $(60,0 \%)$ sebagian besar responden berjenis kelamin laki-laki $(60 \%)$, sebagian kecil responden berada pada tingkat kecemasan berat $(45,0 \%)$. Rata-rata tingkat kecemasan pasien pre operasi apendiksitis sebelum dilakukan tindakan relaksasi nafas dalam dengan aromaterapi lavender 28,70 sedangkan ratarata kecemasan pasien pre operasi apendiksitis sesudah dilakukan tindakan relaksasi nafas dalam dengan aromaterapi lavender 23,70. Ada pengaruh pemberian teknik relaksasi nafas dalam dengan aromaterapi lavender terhadap nilai kecemasan pasien pre operasi dengan perbedaan rata-rata kecemasan sebelum dan sesudah intervensi sebesar 5,00.

Diharapkan dalam melakukan intervensi keperawatan dapat melakukan teknik relaksasi nafas dalam dengan aromaterapi lavender khususnya dalam menanggulangi dan mengurangi kecemasan 
pasien pre operasi apendiksitis sehingga tindakan operasi akan berjalan dengan baik. Diharapkan pada saat pasien pre operasi masuk keruangan perawatan, perawat ruangan dapat melakukan teknik relaksasi nafas dalam dengan aromaterapi lavender kepada pasien tentang prosedur tindaka

\section{DAFTAR RUJUKAN}

Apriansyah, dkk. (2015). Hubungan Antara Tingkat Kecemasan Pre-Operasi dengan Derajat Nyeri Pada Pasien Post Sectio Caesarea di Rumah Sakit Muhammadiyah Palembang Tahun 2014. Jurnal Keperawatan Sriwijaya.

Arwani., Sriningsih, I., \& Hartono, R. (2013). Pengaruh pemberian aromaterapi terhadap tingkat kecemasan pasien sebelum operasi dengan anestesi spinal di RS Tugu Semarang. http://jurnal.unimus.ac.id/index.

$\mathrm{php} / \mathrm{psn} 12012010 /$ article /view/854 diperoleh tanggal 14 November 2013.

Dewi, I. P (2012). Aromaterapi Lavender Sebagai Media Relaksasi. Jurnal Kesehatan Fakultas Kedokteran Universitas Udayana.

Dewi, \& Prima. (2011). Aromaterapi Lavender Sebagai Media Relaksasi. Semarang: Bagian Farmasi Fakultas Kedokteran Universitas Udayana.

Hasri, E.T. (2012). Praktik keselamatan pasien: surgical safety checklist. dengan yang baik. Diharapkan setiap briefing (pertemuan singkat) kepala ruangan dapat untuk mengingatkan ketua tim dan anggota tim untuk selalu menerapkan teknik relaksasi nafas dalam dengan aromaterapi lavender ketika terdapat pasien pre operasi.

http://mutupelayanankesehatan.net/index.php/compo nent/contentarticle/22/585diperoleh tanggal 9 Desember 2013.

Ibrahim. (2008). Gambaran Tingkat Kecemasan Pada Klien Pra Bedah Mayor Di Ruang Rawat Inap Medikal Bedah Gedung D Lantai 3 Rumah Sakit.

Koensomardiyah. (2009).A-Z Aromaterapi Untukkesehatan, kebugaran, dan kecantikan.Yogyakarta: Andi Publisher.

Larasati, dkk. (2009). Efektivitas Preperative Teaching Terhadap Penurunan Tingkat Kecemasan Pasien Preoperasi Di Ruang Rawat Inap RSUD Karanganyar.http://fkip.larasati/.

Pande, NPM Yantini.IGAR Agustini.dkk. (2013). Pengaruh Aromaterapi Lavender Terhadap Kecemasan Pada Pasien Skizofrenia Di Rumah Sakit Jiwa Prvinsi Bali. Jurnal Kesehatan STIKES Bina Usada:Bali. 